\section{Flurprimidol \\ Foliar Sprays and Substrate Drenches Control Growth of 'Pacino' Pot Sunflowers}

\author{
Brian E. Whipker ${ }^{1,2}$, \\ Ingram McCall, \\ James L. Gibson ${ }^{3}$, and \\ Todd J. Cavins ${ }^{4}$
}

Additional Index wORDs. cutless, daminozide, growth retardant, Helianthus annums, paclobutrazol, Topflor

SumMarY. Flurprimidol substrate drenches at $2 \mathrm{mg}$ a.i. per $15.3 \mathrm{~cm}$ ( 6 inch) pot were more effective on 'Pacino' pot sunflowers (Helianthus annuus) than flurprimidol foliar sprays of $\geq 30 \mathrm{mg} \cdot \mathrm{L}^{-1}(\mathrm{ppm})$, but both treatments resulted in significantly smaller plant height and diameter than the control $(28,350 \mathrm{mg}=1$ $\mathrm{oz})$. Flurprimidol drenches of $2 \mathrm{mg}$ were comparable in controlling plant height and diameter to the commercial drench recommendations of $2 \mathrm{mg}$ paclobutrazol. The commercial recommendation of daminozide foliar sprays at $4000 \mathrm{mg} \cdot \mathrm{L}^{-1}$ had greater efficacy in controlling plant height than the most effective flurprimidol foliar sprays of $\geq 30 \mathrm{mg} \cdot \mathrm{L}^{-1}$. Daminozide had no effect on plant diameter, while flurprimidol resulted in narrower plants. Flurprimidol and paclobutrazol drenches of 2

\footnotetext{
This research was funded in part by the North Carolina Agricultural Research Service (NCARS), Raleigh, NC 27695-7643. Use of trade names in this publication does not imply endorsement by the NCARS of products named nor criticism of similar ones not mentioned. Thanks to Benary for the seed, Fafard for the root substrate, Scotts for the fertilizer, Dillen Products for the pots, and for grant support the North Carolina Commercial Flower Growers' Assoc. and SePRO Chemical Co.

${ }^{1}$ Department of Horticultural Science, Box 7609, North Carolina State University, Raleigh, NC 27695-7609.

${ }^{2}$ To whom reprint requests should be addressed.

${ }^{3}$ Dept. of Environmental Horticulture, University of Florida - Milton Campus, 5988 Hwy 90, Bldg. 4900, Milton, FL 32583.

${ }^{4}$ Dept. of Horticulture, $360 \mathrm{Ag}$. Hall, Oklahoma State Univ., Stillwater, OK 74078-6027.
}

mg offer the economic advantage to producers of increased plant density on greenhouse benches, while plants treated with daminozide would require a greater amount of bench area. Producers should evaluate the trade-offs between the added costs of a drench vs. the higher cost-persquare-foot-week of production space required for a daminozide foliar spray. With these options, producers can select a plant growth regulator (PGR) that best fits their production and market requirements.

S hort-growing cultivars of sunflowers are available for use as potted plants, but plant size is still often disproportionate to pot size. Plant growth regulators are commonly applied to container-grown plants to control stem elongation and produce compact plants (Gaston et al., 2001). Marketable sized 'Pacino' potted sunflower plants were produced with daminozide (B-Nine; Uniroyal Chemical, Middlebury, Conn.) foliar sprays of 4000 to $8000 \mathrm{mg} \cdot \mathrm{L}^{-1}$ (Whipker and Dasoju, 1998) or with paclobutrazol (Bonzi; Uniroyal Chemical) drench doses of 2 to $4 \mathrm{mg}$ a.i. per pot (Dasoju et al., 1998). Whipker and McCall (2000) also reported that five cultivars of pot sunflowers responded similarly to the above-recommended concentrations.

Flurprimidol has been labeled as Cutless (SePRO; Carmel, Ind.) for ornamental crop use in the United States and commercially introduced as Topflor (SePRO) in Europe for greenhouse crops. Topflor has been tested on a number of greenhouse plants such as chrysanthemum (Dendranthema xgrandiflorum) (Pobudkiewicz and Nowak, 1997), dianthus (Dianthus caryophyllus) (Pobudkiewicz and Nowak, 1994), cape daisy (Osteospermum ecklonis) (Olsen and Andersen, 1995), and streptocarpus ( Streptocarpus hybridus) (Pobudkiewicz, 2000) in Europe. Commercial recommendations call for foliar sprays of 10 to 30 $\mathrm{mg} \cdot \mathrm{L}^{-1}$ to pot sunflowers (Houska, 1997; Spiess-Urania, 2001). In Europe a $1.5 \%$ flurprimidol formulation is used, while the formulation being introduced into the United States is $0.38 \%$. Reformulated flurprimidol has not been tested on pot sunflowers as a foliar spray and has not been evaluated as a substrate drench. Therefore, this study was conducted to determine 
recommended foliar spray and substrate drench concentrations for height control of 'Pacino' pot sunflowers and compare these treatments with recommended daminozide foliar sprays and paclobutrazol drenches.

\section{Materials and methods}

'Pacino' seeds were sown into 8 $\times 4 \times 5.5 \mathrm{~cm}$ cell packs $(3.1 \times 1.6 \times$ 2.17 inches) on 30 Oct. 2001. On 19 Nov., seedlings were transplanted into $15.3-\mathrm{cm}$-diameter round plastic pots with a volume of $1.23 \mathrm{~L}(1.3 \mathrm{qt})$ and filled with Fafard 4P (Fafard, Anderson, S.C.) substrate. Plants were fertilized at each irrigation with $150 \mathrm{mg} \cdot \mathrm{L}^{-1} \mathrm{ni}^{-}$ trogen using $15 \mathrm{~N}-2.1 \mathrm{P}-12.5 \mathrm{~K}$ (Excel 15-5-15 Cal-Mag; Scotts, Marysville, Ohio). Greenhouse day/night set point temperatures were $23.9 / 18.3$ ${ }^{\circ} \mathrm{C}\left(75 / 65^{\circ} \mathrm{F}\right)$. The plants were grown under natural daylength. Foliar spray treatments consisting of flurprimidol $(0.38 \%)$ at $0,10,20,30,40$, or 50 $\mathrm{mg} \cdot \mathrm{L}^{-1}$ and daminozide at $4000 \mathrm{mg} \cdot \mathrm{L}^{-1}$ were applied on $2 \mathrm{Dec}$. using a volume of $203.7 \mathrm{~mL} \cdot \mathrm{m}^{-2}\left(0.5 \mathrm{gal} / 100 \mathrm{ft}^{2}\right)$. Substrate drench treatments of fluriprimidol at $0,0.5,1,2,3$, or $4 \mathrm{mg}$ a.i. per pot and paclobutrazol at $2 \mathrm{mg}$ a.i. per pot were applied using $118.3 \mathrm{~mL}$ ( $4 \mathrm{fl} \mathrm{oz}$ ) of solution per pot. The experiment was a completely randomized design with eight single-plant replications of the 13 treatments. The number of days to anthesis, total plant height (measured from the pot rim to the uppermost part of the inflorescence), and plant diameter (measured at the widest dimension and turned $90^{\circ}$, and averaged) were recorded.

Data for days to anthesis, plant height, and plant diameter were tested with analysis of variance by general linear model (SAS Institute, Cary, N.C.). Treatment means were separated by least significant differences (LSD) at $P \leq 0.05$. Plant height and diameter values were regressed using the PROC REG procedure to determine the best fit linear or quadratic model for the flurprimidol application methods (foliar spray or substrate drench). Terms of the model were judged to be significant or nonsignificant and included in the final model based on a comparison of $F$ values at $\alpha=0.05$. The NLIN procedure in SAS, as modified by Cox (1992), was used to calculate linearplateau functions (model IV) relating plant height and diameter to flurprimidol substrate drench concentrations.
The quadratic and the linear-plateau models were compared to determine the best fit based on $r^{2}$ values.

\section{Results and discussion}

Foliar sprays. A linear relationship existed between increasing concentrations of flurprimidol foliar sprays and plant height for 'Pacino' pot sunflower (Fig. 1A). Concentrations of flurprimidol $\geq 30 \mathrm{mg} \cdot \mathrm{L}^{-1}$ were required for significantly shorter plants as compared to the untreated control. Plant height was $12 \%$ smaller than the untreated control plants with $40 \mathrm{mg} \cdot \mathrm{L}^{-1}$ flurprimidol. This $40 \mathrm{mg} \cdot \mathrm{L}^{-1}$ flurprimidol rate was greater than the $30 \mathrm{mg} \cdot \mathrm{L}^{-1}$ recommended in Germany by Houska (1997) or the $10 \mathrm{mg} \cdot \mathrm{L}^{-1}$ recommended by Spiess-Urania (2001). Daminozide foliar sprays of $4000 \mathrm{mg} \cdot \mathrm{L}^{-1}$ were more effective than flurprimidol on 'Pacino', with the plants being 30\% shorter than the control. The degree of control achieved with $4000 \mathrm{mg} \cdot \mathrm{L}^{-1}$ daminozide in this study was greater than the $17 \%$ smaller plants reported by Whipker and Dasoju (1998) which may account for the upward orientation of the inflorescence (at a $45^{\circ}$ angle to the stem) instead of parallel to the stem. This change in inflorescence orientation had previously been reported with daminozide rates of $16,000 \mathrm{mg} \cdot \mathrm{L}^{-1}$ (Whipker and Dasoju, 1998).

The higher concentrations of flurprimidol required in this study to achieve a significant response may be due to differences in latitude and climate between Central Europe and the southeastern United States. For example, $4000 \mathrm{mg} \cdot \mathrm{L}^{-1}$ of daminozide is recommended by Whipker and Dasoju (1998) for the United States, while in Central Europe the recommended concentration is $1500 \mathrm{mg} \cdot \mathrm{L}^{-1}$ (Benary Seed Co., personal communication).

'Pacino' plant diameter response to flurprimidol foliar sprays was best fit to a quadratic model (Fig. 1B). Plant diameter was $10 \%$ smaller than the untreated control plants when sprayed with $\geq 30 \mathrm{mg} \cdot \mathrm{L}^{-1}$ flurprimidol. Daminozide foliar sprays of $4000 \mathrm{mg} \cdot \mathrm{L}^{-1}$ were ineffective in controlling plant diameter, which was noted by Whipker and Dasoju (1998).

Substrate Drenches. The response of 'Pacino' plants was best fit to a linear-plateau model with the smallest plants being $30.9 \mathrm{~cm}$ (12.17 inches) tall when treated with $2 \mathrm{mg}$ flurprimidol (the joinpoint, $\mathrm{x}_{0}$ ) or greater (Fig.
1C). No further increases in control occurred at concentrations of $2 \mathrm{mg}$ or greater, the plateau portion of the line. 'Pacino' pot sunflower plants were $22 \%$ shorter when treated with $2 \mathrm{mg}$, when compared to the untreated control plants. Flurprimidol drenches of 2 mg were comparable to paclobutrazol drenches of $2 \mathrm{mg}$, which resulted in plants $20 \%$ shorter than the untreated control. The degree of control achieved in this experiment with a $2-\mathrm{mg}$ paclobutrazol drench, the commercially recommended concentration, was less than the $27 \%$ shorter height reported by Dasoju et al. (1998).

'Pacino' plant diameter was best fit to a linear-plateau model, with no additional response in plant diameter being observed at concentrations of $1.1 \mathrm{mg}$ (the joinpoint, $\mathrm{x}_{0}$ ) or greater (Fig. 1D). 'Pacino' plants treated with $1.1 \mathrm{mg}$ were $17 \%$ smaller in diameter compared to the untreated control. Paclobutrazol drenches of $2 \mathrm{mg}$ resulted in plants that were $16 \%$ smaller in diameter than the untreated control, and the results were similar to earlier reports of $17 \%$ smaller plants (Dasoju et al., 1998). Smaller diameter plants would be advantageous to wholesale producers because a greater number of pots could fit on shipping carts and trucks.

The number of days to anthesis averaged $66 \mathrm{~d}$ and was not affected by the PGR treatments (data not shown). Results are in agreement with earlier research in which daminozide foliar sprays $\leq 8000 \mathrm{mg} \cdot \mathrm{L}^{-1}$ did not delay anthesis (Whipker and Dasoju, 1998). Paclobutrazol drenches of 2 to $32 \mathrm{mg}$ have been reported to delay anthesis by 4 to $6 \mathrm{~d}$ during winter production of pot sunflowers in Iowa (Dasoju et al., 1998), but neither the $2 \mathrm{mg}$ paclobutrazol nor flurprimidol drenches of $\leq 4 \mathrm{mg}$ delayed anthesis in our study.

\section{Conclusions}

Flurprimidol substrate drenches at 2 mg were more effective on 'Pacino' pot sunflowers than flurprimidol foliar sprays of $\geq 30 \mathrm{mg} \cdot \mathrm{L}^{-1}$, and both resulted in significantly smaller plant heights and diameters of 'Pacino' pot sunflowers than the untreated control. The commercially recommended daminozide foliar sprays of $4000 \mathrm{mg} \cdot \mathrm{L}^{-1}$ were more effective in controlling plant height than flurprimidol foliar sprays of $\geq 30$ $\mathrm{mg} \cdot \mathrm{L}^{-1}$, but daminozide had no effect 


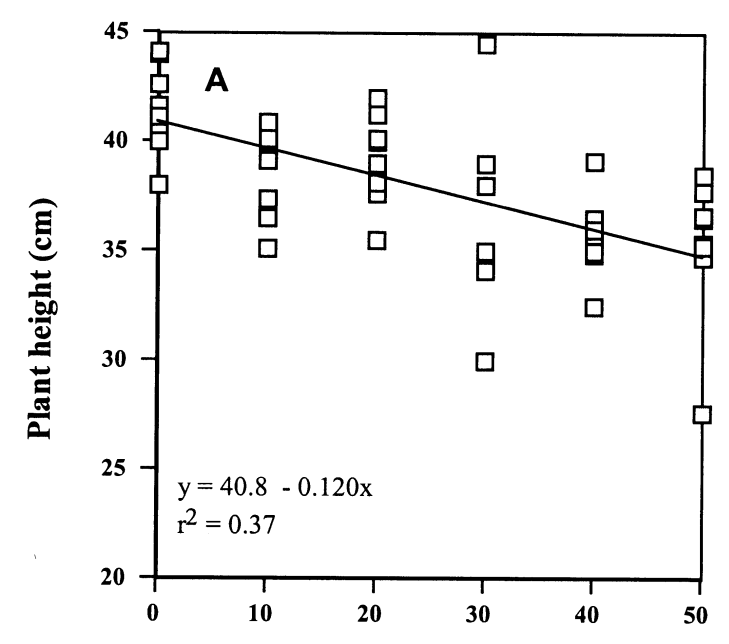

Concentration $\left[\mathrm{mg} \cdot \mathrm{L}^{-1}(\mathrm{ppm})\right]$

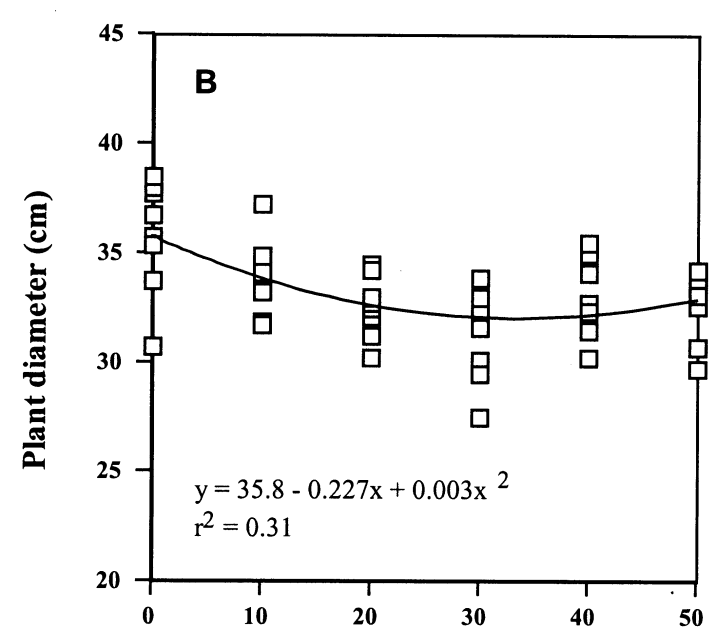

Concentration $\left[\mathrm{mg} \cdot \mathbf{L}^{-1}(\mathbf{p p m})\right]$

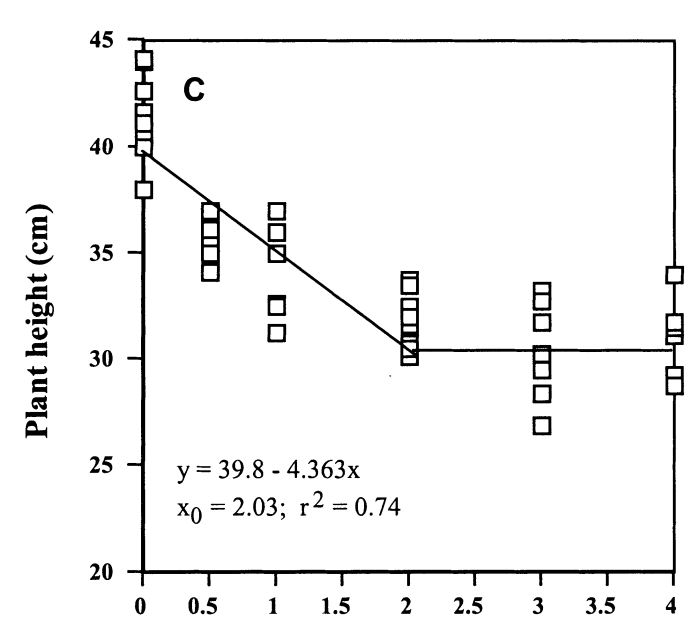

Dose (mg a.i.)

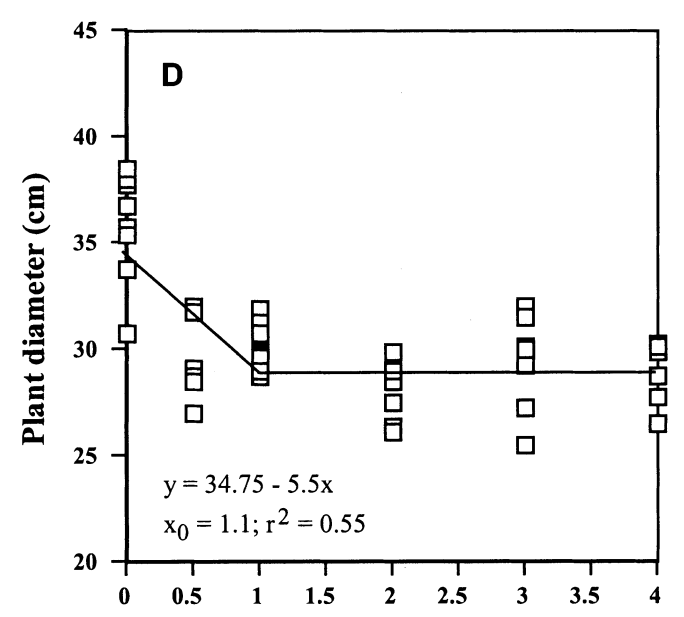

Dose (mg a.i.)

Fig 1. Flurprimidol foliar spray and drench effects on 'Pacino' potted sunflower height and diameter. Regression lines were generated from the best-fit model $(n=8)$. (A) Flurprimidol foliar spray effects on plant height. (B) Flurprimidol foliar spray effects on plant diameter. (C) Flurprimidol substrate drench effects on plant height. (D) Flurprimidol substrate drench effects on plant diameter. $2.54 \mathrm{~cm}=1.0 \mathrm{inch} ; 28,350 \mathrm{mg}=1 \mathrm{oz}$.

on plant diameter. Flurprimidol and paclobutrazol drenches of $2 \mathrm{mg}$ offer the economic advantage to producers of increased plant density on greenhouse benches, while plants treated with daminozide would require a greater amount of bench space. The weekly costs per square foot for a greenhouse operation would be allocated over a larger number of plants and results in lower per-pot production costs. Producers should evaluate the tradeoffs between the added chemical and labor costs of applying a drench vs. the higher weekly costs-per-square-foot for production space required with a daminozide foliar spray. With these options, producers can select a PGR that best fits their production and market requirements.

\section{Literature cited}

Cox, F.R. 1992. Range in soil phosphorus critical levels with time. Soil Sci. Soc. Amer. J. 56:1504-1509.

Dasoju, S., M.E. Evans, and B.E. Whipker. 1998. Paclobutrazol drenches control growth of potted sunflowers. HortTechnology 8:235-237.

Gaston, M.L., P.S. Konjoian, L.A. Kunkle, and M.F. Wilt (eds.) 2001. Tips on regu- lating growth of floriculture crops. Ohio Florists Assn. Serv., Columbus, Ohio.

Houska, P. 1997. Helianthus annums Hemmstoffe. Research report of Lehr- und Versuchsanstalt fur Gartenbau, HannoverAhlem, Germany

Olsen, W.W. and A.S. Andersen. 1995. Growth retardation of Osteospermum ecklonis. Acta Hort. 397:129-138.

Pobudkiewicz, A. and J. Nowak. 1994. The influence of flurprimidol and uniconazole on growth of the CMM dwarf Dianthus caryophyllus L. cv. Snowmass. J. Fruit Ornamentals Plant Res. 2(4):43-52. 
Pobudkiewicz, A. and J. Nowak. 1997. Response of chrysanthemum (Dendranthema grandiflora Kitam) cvs. Altis and Surf to flurprimidol application. J. Fruit Ornamentals Plant Res. 5(1):135-142.

Pobudkiewicz, A. 2000. Controlling the growth habit of Streptocarpushydrideswith flurprimidol. J. Fruit Ornamentals Plant Res. 8(1):9-17.

Spiess-Urania. 2001. Topflor, p. 464-472. In: Spiess-Urania Chemicals GMBH Produktinformation 2002, Hamburg, Germany.

Whipker, B.E. and S. Dasoju. 1998. Potted sunflower growth and flowering responses to foliar applications of daminozide, paclobutrazol, and uniconazole. HortTechnology 8:86-88.

Whipker, B.E. and I. McCall. 2000. Response of pot sunflower cultivars to daminozide foliar sprays and paclobutrazol drenches. HortTechnology 10:209-211. 